\title{
Model for construction project delay occurrence (PDO)
}

\author{
Ehab Soliman and Khaled Alrasheed* \\ Kuwait University, Civil Engineering Department, Safat 17269, Kuwait \\ *Corresponding author: k.alrasheed@ku.edu.kw
}

Submitted: 10/04/2020

Revised: $\quad 08 / 12 / 2020$

Accepted: 19/12/2020

\begin{abstract}
Extensive research work was conducted in relation with evaluating and ranking delay causes in construction projects, but limited research was performed to discuss the delay issue in theory. This paper discusses the theoretical basis for how delay occurs and propagates during project construction. A set of suggested assumptions were proposed to build a theoretical model for delay occurrence. These assumptions were driven from the analysis of construction project environment, and the concept of project implementation. The construction delay occurrence (PDO) model assumes that some of the root delay causes can convert by themselves and/or other triggers toward direct delay causes. Contractor management deficiency, project contract and procurement strategy, and contractor financial problems are examples of the root delay causes, which have significant influence on project delay and resource availability. The model assumes that construction resources unavailability is the underpinning driver for project delay. Graphical presentation of the PDO model is used to illustrate how delay is generated, propagated during the project life, and converted to be a real and physical delay. Interview questionnaires were used to verify the model bases. This is followed by statistical analysis to ascertain the model assumptions and Delphi technique to confirm questionnaire results. The correlation factors for the two rounds of questionnaires showed that there is a great enhancement for respondents' answers regarding the effect of resource shortage on root delay causes. The study shows that the proposed set of root delay causes and their effect on project delay and their influence on resource availability were statistically accepted. The study results can be used as a basis for assessing root delay causes and predicting the prone of a project to delay before it starts.
\end{abstract}

Keywords: Project delay; Delay modeling; Statistical analysis; Delphi.

\section{INTRODUCTION}

Construction is among high-risk industries with major concerns related to project time and cost control (Callahan, et al., 1992). Maintaining control on project planned schedule has always been a challenge and a key success indicator (Clough et al., 2000). Globally, it is recorded that many construction projects were and are at risk of delays. Studies recorded that 40 per cent of construction projects in India (Iyer and Jha, 2006), 70 per cent of public construction projects completed the UK (Shebob et al., 2012), and 38 per cent of construction projects for major public projects in Oman (Ruqaishi and Bashir, 2013) were finished beyond their contractual time. In addition to the risk of missing completion date, construction delays have severe consequences on the allocated budget and work productivity, and it could expose the project to contract termination (Arditi \& Pattanakitchamroon 2008). Project delay has many drawbacks for construction performance, and it continues to be a major industry challenge toward avoiding costly disputes and hostile relationships amongst parties involved (Al-Khalil and Al-Ghafly, 1999).

As a result, related studies continue world-wide to deal with construction delays. These studies can be divided into two main groups: studies aimed to measure and rank actual delay causes, while the other group concentrating on the methods to resolve and evaluate delay claims. Despite the on-going research activities, it lacked focus on the reasons 
behind delay occurrence from a theoretical basis. This paper discusses the theory of why the delay in construction projects occurs, and how it propagates through the project life cycle.

\section{OBJECTIVE}

This study aims to propose a theoretical model by deeply investigation previous research work regarding construction project delays and principals of construction management theories. The resulted theoretical basis model discusses how the delay occurred or how the delay propagated in construction projects. The model takes into consideration the phenomena of root causes and resource supplying principals. Root delay causes can be identified or predicted before delay occurrence. The model supposes that the project delay is born in earlier stage by root delay causes triggers that affect resource availability resulting in project delay. This model can be used as a tool for analyzing how the project delays occurred in construction projects. The model bases should be verified by construction management personnel.

\section{BACKGROUND}

Construction project delay is very common. Stumpf (2000) defines delay for an activity as an act or event extending the required time to perform the contract tasks. It often appears as additional days of work or as a delayed start or finish of an activity. Mohamad (2010) defines delay as an act or event that extends the time to complete or perform an act under the contract. Also, Assaf and Al-Hejji (2006) state that delay is the time overrun either beyond completion date specified in a contract, or beyond the date that the parties agreed upon for delivery of a project. These definitions compare the actual duration for an activity or whole project to original or planned ones.

Because construction project delay is a global phenomenon and there are many drawbacks of it, many studies were conducted worldwide to discuss this problem. The conducted research work for construction projects are divided into two main areas: identifying and ranking delay causes, and delay claim analysis. Many research works have measured and ranked delay causes according to their importance. More than 60 studies have been recorded and published in the last three decades. These studies covered almost world counties. These studies started by Baldwin et al. (1971) in the USA and continue to attract researchers. Examples of some of the new studies in this area are: Mahdi and Soliman (2018) for Arabian gulf area construction projects, Muneeswaran et al. (2018) for India, Rachid et al. (2018) for Algeria, and Bajjou and Chafi (2018) for Morocco. Because of the huge number of studies in this area, Soomro et al. (2016), Saiful Islam and Trigunarsyah (2017), and Ramanathan et al. (2012) summarized most of these studies around the world.

The other group of research work aimed to identify the techniques to resolve problems that resulted from construction project delays such as delay claims and disputes. Most of these techniques depend on analysis of project critical path during project life. These techniques aim to identify who is responsible for the delay and how to compensate other project parties. Yang and Kao (2009), Bubshait et al. (1998), and AlKass et al. (1996) and many others discussed the available techniques in this area. Predicting major delay sources before construction is vital for project parties to alleviate these delay sources and apply proactive measures (Zayed and Kalavagunta, 2005).

Despite the huge number of studies conducted in this research area, extremely limited research work has been conducted to discuss the problem in theoretical basis. How this problem occurs, why it happens, and how it propagates during project life?

This study attempts to investigate delays in construction projects and propose a theoretical basis model to answer the question why construction projects are delaying. This model depends on many of assumptions that are resulted from analyzing construction project environment and by studying previous research work regarding project delay causes and analysis. 


\section{RESEARCH METHODOLOGY}

The study goes through these steps as shown in Figure 1

1- Literature review: many research works have been conducted worldwide in the last three decades to measure the delay causes in construction projects. Most of these studies concentrated on identifying the most important delay causes either qualitative from construction personnel judgment or quantitative by measure most repetitive delay causes. A quick review for these studies is done to identify the root delay causes.

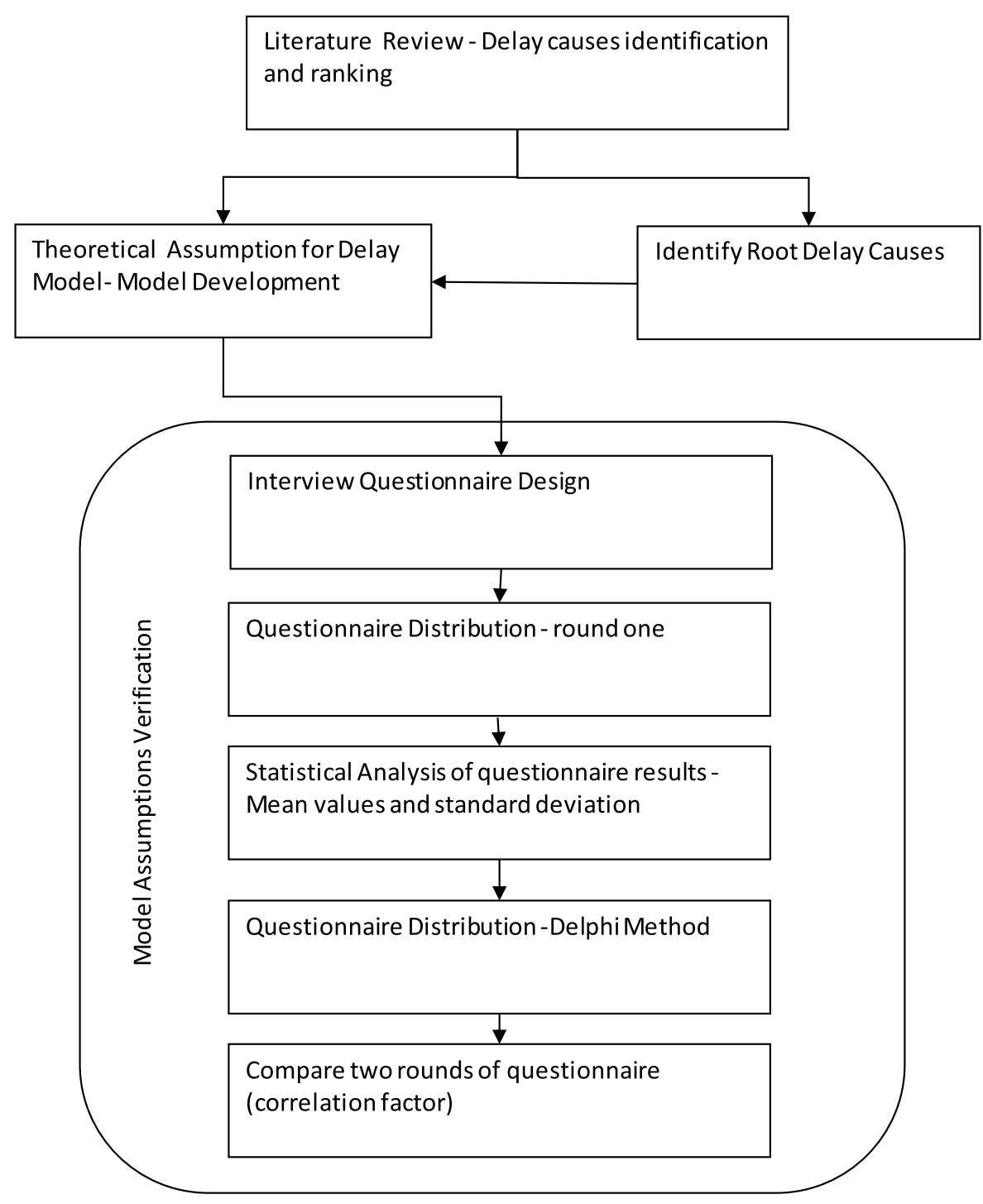

Fig. 1. Research methodology.

2- Analyze why delay happening in theory: a deep investigation of the relationship between delay occurrence and many other triggers that can be converted themselves or by other influencers to be direct delay causes.

3- Develop a theoretical model to predict delay occurrence in future by putting a set of assumptions for the proposed theoretical model. The model depends on some of theoretical assumptions, which resulted from a deep analysis of construction project anatomy and construction management theories. 
4- To verify the principals of the proposed theoretical model, an interview questionnaire with a group of construction personnel is held. An interview questionnaire is held in two rounds, the first round with thirty participants. Each participant has the adequate experience and knowledge to evaluate and judge model basis. Delphi method of a second round of questionnaire with eight participants in to confirm round one results.

5- Round one questionnaire data gathering is statistically analyzed to verify proposed theoretical basis model. Mean value and standard deviation were used as a basis for accepting the relationship between theory basis and relationship with resource availability.

6- Delphi method is used to confirm and enhance round one questionnaire results. correlation analysis is used to evaluate the difference between the rounds of the interview questionnaire.

\section{CONSTRUCTION PROJECT DELAY OCCURRENCE (PDO) MODEL DEVELOPMENT}

\section{Theoretical basic discussion}

The primary product of construction projects consists of an interrelated set of tasks and activities. The activity performance time is directly affected by two sets of factors: external and internal. External factors, usually, are beyond the influence and control of the managing team, and can directly affect an activity's performance time. Such factors include changing global economic conditions, government regulations and weather conditions. On the other hand, the internal factors - managerial, financial and technical - are within the control of the managing team, and are determined by the managing team's efficiency. They can, indirectly, affect an activity's performance time by their direct effects on the efficiency of the resource supply chain of the required resources for construction. These internal influencers are assumed to be the driving cause behind the resource supply inefficiency. They are generated and propagated through project life.

The above discussion can be presented in Figure 2 in four interrelated categories of influence. The categories are:

- Category 1: noncontrolled external affecters - out of study scope

- Category 2: Internal controlled management aspects - internal factors

- Category 3: Resource supply chain management - Resources

- Category 4: project activity - tasks

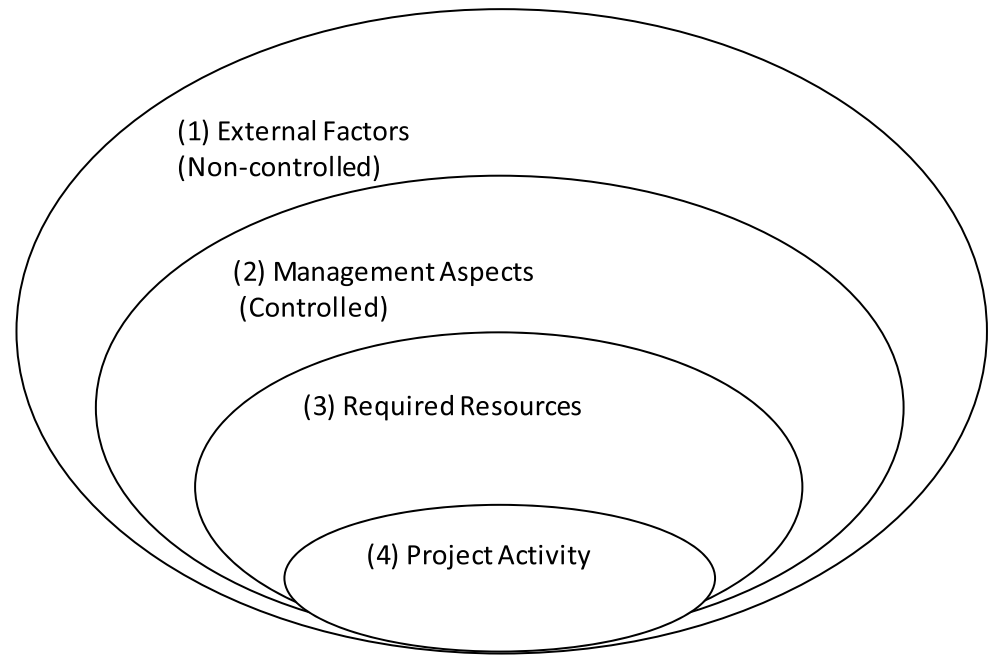

Fig. 2. Level of impact on construction activity duration. 
With the above discussion, Category (2) - internal affecters would be the most significant elements in managing project delays. They impact the availability and performance of the required resources, which lies in Category (3), determining the time performance of an activity. This study will focus on the internal factors that indirectly affect the activity time performance. As for the external factors, they are, usually, covered in the contract documents and can easy be identified during project life. Therefore, they are excluded from this study.

\section{Model Assumptions}

The model was developed theoretically based on three assumptions: delay is a dynamic event and not static, delay is generated early by a set of root delay causes, and resource shortage is the driving cause for construction delay.

\section{Assumption 1: Delay is a Dynamic Event Not Static.}

The model assumes that a chain of sequential steps results in project delay. The delay is generated/initiated from a deficiency of one or more of early influencers (root delay causes). The minor delay, less significant and/or unnoticed, is propagated during the project life cycle to become a major direct delay by self-triggers, external triggers or a combination of both. Therefore, the delay process should be dynamic from the project concept, continuing during the construction project life to prevent and mitigate the effect of delay occurrence.

\section{Assumption 2: Concentrate on Root Delay Causes instead of direct delay causes}

Root-cause analysis (RCA) is one of the methods that have been developed to identify the causes of unfavorable events to prevent them from reoccurring (Aurisicchio et al., 2016). Andersen and Fagerhaug (2006) considered root cause analysis as the practice that looks deeply into the chain of events before an undesired event to identify its primary causes. There are many studies on the application of root causes analysis in the construction management field. Rosenfeld (2013) used the method of root causes analysis in order to understand the construction cost overrun primary causes. As a result of his study, fifteen independent universal primary causes for construction cost overrun were identified. Battikha (2008) used root causes analysis to identify the causes of collapse in construction projects. He used the cause-effect relationship between the collapse disaster and core reasons to illustrate the collapse occurrence. (Sweis et al., 2018) used an approach of determining root delay causes for Iranian oil projects in three steps; brainstorming, data gathering then data analysis. They resulted in 24 root delay causes grouped into five groups of external, operational, financial, site, human and equipment groups of root delay causes. (Hsu et al., 2017) used fault tree analysis to investigate the primary delay factors for a case study project. They reached 12 primary delay factors. Unfortunately, most of the resulted delay causes from (Sweis et al., 2018 and Hsu et al., 2017) are direct causes that can be used as basis for claim and delay analysis and these causes may have resulted from another root causes. Soliman (2006) studies the root delay causes in construction projects by using cause-effect technique. He analyzed 53 general direct delay causes gathered from literature and reached fourteen delay causes. These set of root delay causes are mainly managerial, financial and uncontrolled root causes.

As noticed, the idea of root delay causes attracted many researchers in recent years. So, it is more beneficial in managing construction delay project to focus on root delay causes instead of deal with the effect of real or direct delay. The root delay cause can be generated earlier than the real delay occurred. These root delay causes (internal affecters) contain all managerial, financial and other project management talents that can affect the availability of required activity resources as mentioned in the above discussion.

Samples of root delay causes from previous studies such as

- Designer management efficiency

- Quality of contract documents

- Contractor management efficiency 
- Client financial ability

- Communication level efficiency between project parties

- Level of interactions in the preconstruction stage

- Trust between project parties

\section{Assumption 3: Resource Shortage is the driving Source of Construction Delay}

There are two theories behind this assumption, the resource-based theory and the supply chain theory. Resources contribute to the accomplishment of project activities such as manpower, material, money, equipment, time or space. The crucial factor in the successful implementation of a construction project not only depends on the quality \& quantity of work, but also largely depends on the availability of resources (Nagaraju et al., 2012). There is no doubt that efficient of resource management is one of the keys for construction project success as stated by (Ramlee et al., 2015).

The resource-based theory is attributed by Penrose and was developed in 1959. This theory aims to understand how organizations achieve competitive advantage with the application of estimable physical and nonphysical resources at the firms' disposal. It focuses on the importance of resource management as a key for business competence (Kor and Mahoney 2004). This theory represents the importance of resource management of any organization to achieve its goal in a competitive environment such as construction project environment.

Chen and Paulraj (2004) defined the supply chains as a "network of materials, information, and services processing links with the characteristics of supply, transportation, and demand". Ho et al. (2015) defined supply chain management as the philosophy of management that involves the management and integration of a set of selected key business process from end-user through original suppliers, that provides products, services, and information that add value for customers and other stakeholders through the collaborative efforts of supply chain members.

Supply chain principals attracts applications in many sectors of business, and the construction industry was not an exception. Wibowoa and Sholeha (2015) evaluated the supply chain performance in the construction of road projects. They revealed that the measurement of supply chain performance is medium score or good enough for road projects. Gor and Pitroda (2018) evaluated the usage of supply chain management in material supplying barriers in construction sites. They concluded that supply chain management can be considered as the coordination of organization between material flow and information flow. Meng (2012) studied the influence of supply chain relationships on project performance in construction. The study revealed that the adoption of supply chain collaboration and partnering helps to solve the performance problems. It is obvious the remarkable effect of the efficiency of managing resources on construction delay; but, there was no evidence of research work on the principals of supply chain in resource supply efficacy and its direct relationship with project delay. Therefore, and based on the previously made assumptions, a model is proposed in Figure 3.

\section{Model illustration and Presentation}

Since delay is generated from a set of root delay causes and due to the dynamic nature of construction works, modest efforts would reduce the effects of the root delay causes, resulting in a valuable reduction or avoidance of delays. So, lack of effort in managing the root delay causes will result in a shortage of one or more of resources, this will impact one or more of current and/or future project activities execution. Deficiency of efforts in alleviating the impact of resource inefficiency on affected activities, will extend the original activities duration. Should these activities lie on the critical path of the program, the over-all program duration date will be at the risk of delay. Noncritical activities would face reductions in their free and total floats increasing the delay risk for both the activities and the project as a whole. 


\section{CONSTRUCTION PROJECTS DELAY OCCURRENCE (PDO) MODEL VERIFICATION}

\section{Data collection and questionnaire design}

The principals of the model are verified by using a questionnaire with industry personnel. The questionnaire was conducted in two rounds of interviewing and discussing the model basis with construction industry personnel. The face-to-face interview style was adopted to enhance respondents' understanding of questions, and to give the interviewer more control of the questionnaire session. Also, the interview style avoided reading the questions along with restricted options since respondents would almost be affected by the last choice (Kronsnick and Alwin, 1987). This approach, participants had larger space for self-expression.

The questionnaire consisted of two sections; section one described the purpose and the background of the PDO model and purpose of the questionnaire. The second section contained questionnaire questions. The opening discussion with participants was based on the research background to remove barriers and reluctant toward positive interviews. The questions were of closed type, and participants were asked for their evaluation on the effect of each one of the root delay causes in each type of resources' shortage. The root delay causes used in this questionnaire resulted from Soliman (2017). A copy of the used questionnaire is shown in Appendix 1

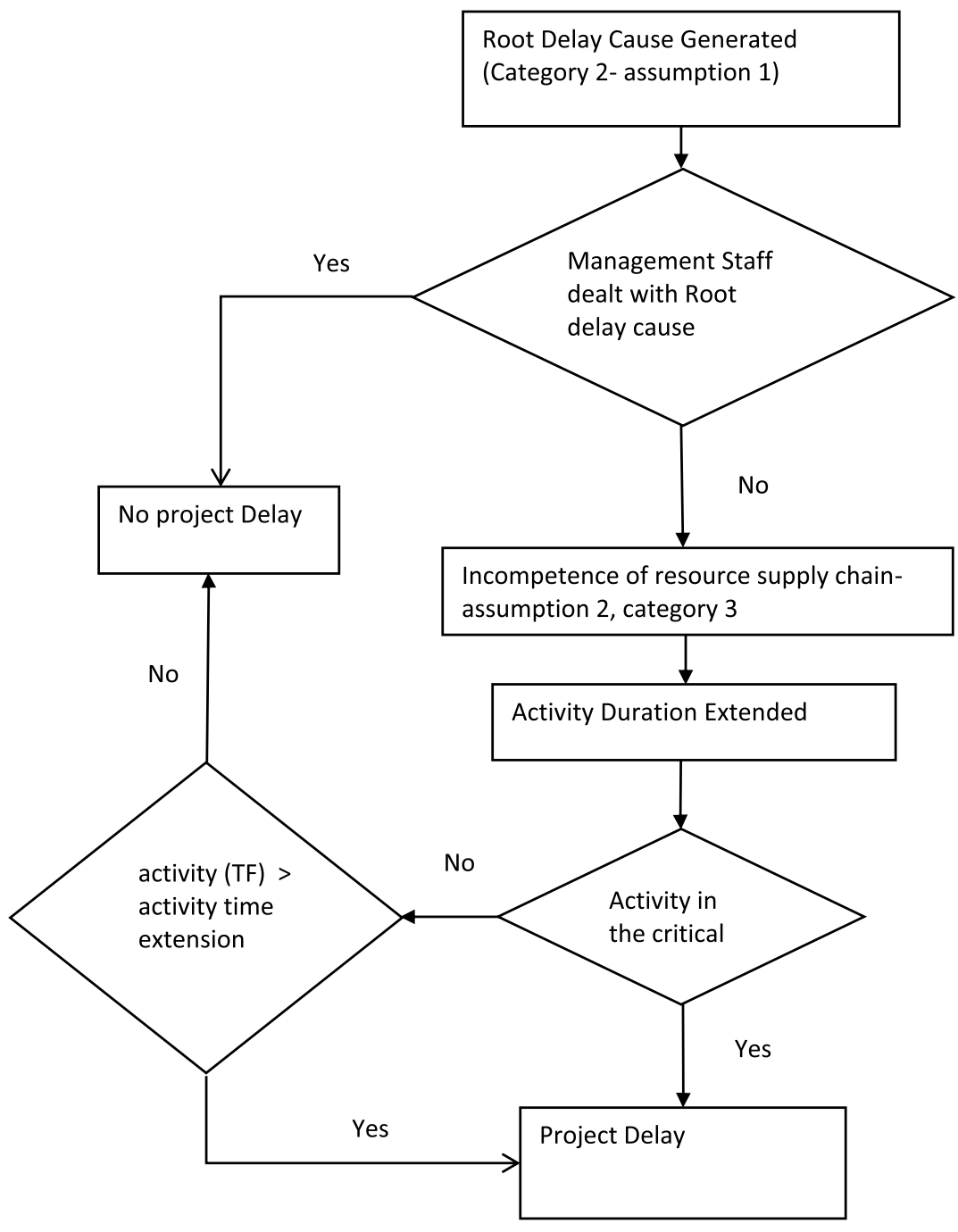

Fig. 3. Project Delay Occurrence (PDO) Model. 
First, participants were introduced with the definition of each one of the main construction resources. These resources were construction materials, labor, equipment, workspace, and information. Materials may be in the form of individual, mixed or fabricated materials needed to execute the construction activities. Labor includes technical, skilled and unskilled labor associated to any of the project activities. Equipment includes all types required to the project activities. Information refers to the project's documents, i.e. working drawings, supervision checklist, specifications, along with other supervision, coordination, orientation information needed in construction. Workspace refers to the environment facilities needed for construction activities to start and finish. It includes the area of construction, light, and work environment. Questionnaire participants were asked for their evaluation of the level of effect of root delay cause to resource shortage. This level was divided into levels varying from very high to very low effect in five Likert scale.

Fifty-eight experts were invited to participate in the study. First, the purpose of the study was presented via a phone call to every participant. Followed by a copy of questionnaire via fax or email for those who accepted the invitation to participate. Then appointments were set for the questionnaire interview session. A total of eight from client-side, nine from consultant firms and thirteen from contracting companies, resulting in thirty construction persons accepted to participate in this study. All of them had the required experience to evaluate research requirements. All had 10 years or more of experience in the construction industry. Thirty structured questionnaire interview sessions had been held by the author. The duration of each interview questionnaire session was around 1.5 hours. The project staff offices were the place of all the interviews.

\section{Analysis of Statistical Data}

SPSS for Windows ${ }^{\complement}$ (Version 24, 2017) was used as the statistical analysis tool for the questionnaire response answers. The Statistical data analysis contained descriptive statistical analysis of the mean, mode, variance and standard deviation. The Delphi method, then, was used to confirm and enhance the results of round one.

Benjamin and Cornell (1970) suggested two conditions should be fulfilled to statistically accept criteria or proposed variable:

1- The mean value of the respondents should equal or exceed the average set in the Likert scale.

2- The standard deviation of the responses should be less than one.

These two conditions were considered for the statistical acceptance of model bases.

\section{Round One: Root Causes and Effect on Resources'Shortage}

Table 1 shows mean values and standard deviation values for the root delay causes and their effect in resources shortage occurrence. The mean value is calculated based on Likert scale in 5 level points. Regarding effects of root delay causes on material shortage and based on the mean values, it can be noticed that contractor financial stability, contractor management deficiency and client financial stability are the causes of most important effect on material shortage occurrence. This not surprising as the material shortage is very sensitive to finance availability. Only site and project characteristics can meet the two conditions of acceptance mentioned before.

For labor and based on mean values, the most important root delay causes that affect the labor shortage are the contractor financial stability and inefficiency of contractor management. The contractor is mainly responsible for planning, arrangement and orientation of construction labor. Many of management arrangements should be applied before using labors in construction projects. Choosing the proper type of labor, number of laborers and site labor management are very crucial for labor shortage in the construction project. The ability to finance laborers hiring and giving laborers their wages in the correct time is very important for labor supply rate. 


\begin{tabular}{|c|c|c|c|c|c|c|c|c|c|c|c|c|c|c|c|}
\hline \multirow{2}{*}{$\begin{array}{l}\text { Еँ } \\
\text { ڤँ }\end{array}$} & 这 & 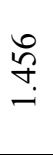 & $\stackrel{n}{\underline{n}}$ & ণn & $\stackrel{?}{\stackrel{?}{\sim}}$ & $\begin{array}{l}\hat{n} \\
=\end{array}$ & 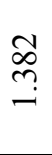 & $\stackrel{\cong}{\rightleftarrows}$ & $\stackrel{\infty}{\stackrel{\infty}{\sim}}$ & $\begin{array}{l}\text { Oे } \\
\text { ก̣ }\end{array}$ & $\stackrel{\bullet}{\bullet}$ & సે & $\begin{array}{l}\text { ᄋे } \\
\text { ก̣ }\end{array}$ & $\begin{array}{l}\mathfrak{6} \\
\stackrel{-}{=}\end{array}$ & f \\
\hline & 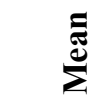 & $\begin{array}{l}\hat{\sigma} \\
\stackrel{+}{\sim} \\
\text { i }\end{array}$ & $\vec{i}$ & $\begin{array}{l}\hat{\sigma} \\
\dot{m}\end{array}$ & $\ddot{m}$ & $\begin{array}{l}\hat{\delta} \\
\stackrel{+}{i} \\
\stackrel{1}{0}\end{array}$ & $\underset{\stackrel{\overbrace{}}{\vartheta}}{\stackrel{\sim}{\sim}}$ & $\begin{array}{c}\text { ஸे } \\
\text { ஸे }\end{array}$ & $m$ & $\vec{\sim}$ & $\underset{\stackrel{m}{i}}{\stackrel{m}{i}}$ & $\stackrel{\nabla}{\sim}$ & भे & $\begin{array}{l}\hat{\sigma} \\
\stackrel{n}{n}\end{array}$ & 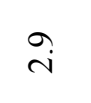 \\
\hline \multirow{2}{*}{ 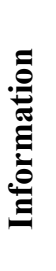 } & 这 & $\begin{array}{l}\bar{r} \\
\hat{0}\end{array}$ & 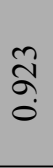 & $\underset{\stackrel{+}{\infty}}{\stackrel{\sim}{-}}$ & 光 & $\begin{array}{l}\infty \\
\text { gे } \\
\text { o }\end{array}$ & 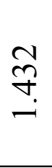 & $\begin{array}{l}\stackrel{\Xi}{\leftrightarrows} \\
=\end{array}$ & 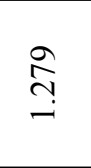 & $\frac{\sim}{n}$ & $\begin{array}{l}\infty \\
\infty \\
\infty \\
0\end{array}$ & ले & $\stackrel{\text { ra }}{-}$ & $\begin{array}{l}n \\
\infty \\
\text { N̦ }\end{array}$ & $\stackrel{n}{n}$ \\
\hline & 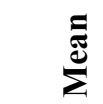 & $\dddot{\sim}$ & ले & $\begin{array}{l}\ddot{n} \\
\dot{m}\end{array}$ & 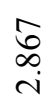 & $\begin{array}{l}\hat{\sigma} \\
\text { r. }\end{array}$ & $\tilde{n}$ & $\begin{array}{l}\hat{\sigma} \\
\dot{0} \\
\dot{m}\end{array}$ & $\begin{array}{l}m \\
\tilde{n} \\
m\end{array}$ & $\tilde{m}$ & $\begin{array}{l}\hat{\sigma} \\
\dot{m}\end{array}$ & $m$ & $\begin{array}{l}\hat{\overbrace{}} \\
\hat{0} \\
\text { ri }\end{array}$ & $\begin{array}{l}\hat{\sigma} \\
\circ \\
\dot{m}\end{array}$ & $\frac{\ddot{m}}{\dot{m}}$ \\
\hline \multirow{2}{*}{ 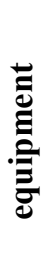 } & 苟 & $\stackrel{N}{\Xi}$ & $\stackrel{n}{=}$ & $\frac{\infty}{i}$ & 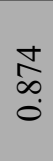 & $\stackrel{\Omega}{\Xi}$ & $\begin{array}{l}n \\
\stackrel{n}{=}\end{array}$ & $\begin{array}{l}\stackrel{\Xi}{\Xi} \\
\stackrel{\Xi}{二}\end{array}$ & $\stackrel{\vec{m}}{\stackrel{\text { f }}{.}}$ & $\begin{array}{l}\stackrel{+}{n} \\
\stackrel{n}{-}\end{array}$ & $\begin{array}{l}\stackrel{\circ}{\beth} \\
=\end{array}$ & $\frac{m}{a}$ & 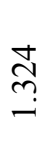 & $\bar{m}$ & 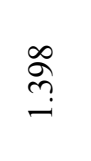 \\
\hline & 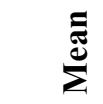 & $\begin{array}{c}\hat{\sigma} \\
\underset{\sim}{v}\end{array}$ & $\begin{array}{l}\hat{\sigma} \\
\stackrel{+}{+} \\
\stackrel{1}{0}\end{array}$ & $\begin{array}{l}\hat{\sigma} \\
\stackrel{\sim}{\forall}\end{array}$ & $\begin{array}{l}\hat{\sigma} \\
\dot{+}\end{array}$ & $\stackrel{\nabla}{\sim}$ & $\begin{array}{l}m \\
m \\
m\end{array}$ & \begin{tabular}{l}
$\hat{\sigma}$ \\
\multirow{2}{*}{}
\end{tabular} & $\begin{array}{l}\hat{\sigma} \\
i \\
i\end{array}$ & $\begin{array}{l}0 \\
i\end{array}$ & $\begin{array}{l}\hat{\sigma} \\
\text { m} \\
m\end{array}$ & $\begin{array}{l}\hat{\sigma} \\
\stackrel{\sim}{i}\end{array}$ & $\stackrel{\sim}{n}$ & $\begin{array}{l}\hat{\sigma} \\
\text { ஸे }\end{array}$ & $\vec{m}$ \\
\hline \multirow{2}{*}{ 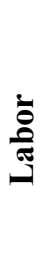 } & 这 & 志 & $\begin{array}{l}\hat{\infty} \\
\infty \\
0 \\
0\end{array}$ & 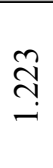 & $\begin{array}{l}\infty \\
0 \\
? \\
0\end{array}$ & 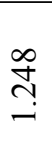 & $\begin{array}{l}\cong \\
\cong\end{array}$ & $\overline{\hat{\sigma}}$ & $\frac{n}{a}$ & ஓே & $\underset{⿱}{\stackrel{\Xi}{\Xi}}$ & 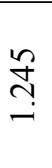 & $\begin{array}{l}\text { ț } \\
\stackrel{0}{0}\end{array}$ & $\begin{array}{l}\hat{ᄋ} \\
\stackrel{0}{0}\end{array}$ & $\hat{n}$ \\
\hline & $\stackrel{\Xi}{\Xi}$ & $\begin{array}{l}\hat{6} \\
\infty \\
-\end{array}$ & $\stackrel{\infty}{-}$ & $\begin{array}{l}\hat{\sigma} \\
\dot{m}\end{array}$ & $\begin{array}{l}\stackrel{m}{\sigma} \\
\dot{v}\end{array}$ & $\stackrel{+}{\sim}$ & $\begin{array}{l}\stackrel{\vartheta}{\sigma} \\
\dot{m}\end{array}$ & $\begin{array}{l}\hat{\sigma} \\
i\end{array}$ & I. & $\overrightarrow{\mathrm{i}}$ & 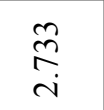 & $\begin{array}{l}\hat{\sigma} \\
\tilde{\sim} \\
\text { in }\end{array}$ & $\begin{array}{l}\hat{\sigma} \\
\stackrel{0}{i} \\
\text { in }\end{array}$ & 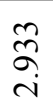 & $\stackrel{\widetilde{\Omega}}{\widehat{\sim}}$ \\
\hline \multirow{2}{*}{ } & 这 & $\stackrel{\sqrt[n]{n}}{\stackrel{n}{=}}$ & ஸ̃ & $\stackrel{\stackrel{\overbrace{}}{\stackrel{\leftrightarrow}{-}}}{.}$ & ○̊ & 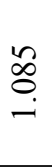 & 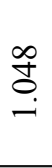 & $\hat{0}$ & $\begin{array}{l}\stackrel{N}{\Xi} \\
=\end{array}$ & $\vec{\nabla}$ & 훙. & $\overrightarrow{\text { m }}$ & 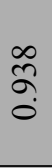 & $\begin{array}{l}\infty \\
\infty \\
\infty \\
0\end{array}$ & $\underset{\sim}{\stackrel{\Delta}{0}}$ \\
\hline & 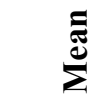 & $\begin{array}{l}\hat{\sigma} \\
\stackrel{n}{i}\end{array}$ & $\begin{array}{l}\hat{\sigma} \\
\infty \\
ن \\
ن\end{array}$ & भे & 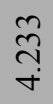 & $\begin{array}{l}\text { ஸे } \\
\hat{\infty} \\
\dot{N}\end{array}$ & $\begin{array}{l}\hat{\sigma} \\
\text { ஸे }\end{array}$ & $\stackrel{\nabla}{\sim}$ & $\underset{\hat{~}}{\tilde{\sigma}}$ & $\begin{array}{l}\hat{m} \\
\hat{\infty} \\
\dot{N}\end{array}$ & $\stackrel{m}{m}$ & $\begin{array}{l}\hat{m} \\
\hat{\infty} \\
\dot{N}\end{array}$ & $n$ & $\begin{array}{l}\hat{\sigma} \\
n \\
m\end{array}$ & $\begin{array}{l}\hat{\sigma} \\
\dot{m}\end{array}$ \\
\hline & 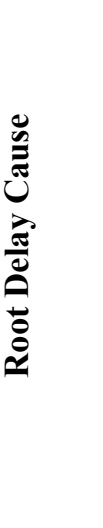 & 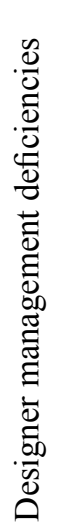 & 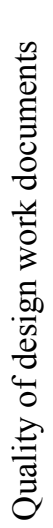 & 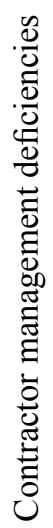 & 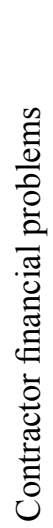 & 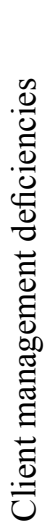 & 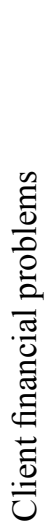 & 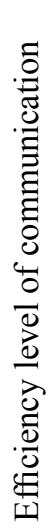 & 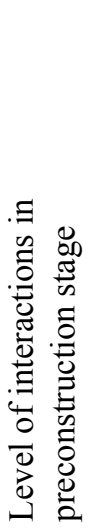 & 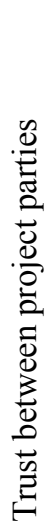 & 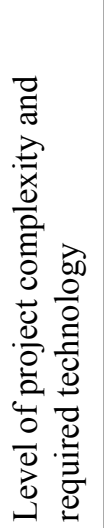 & 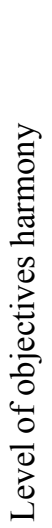 & 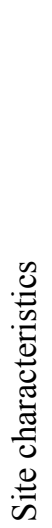 & 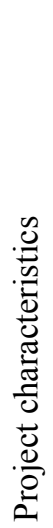 & 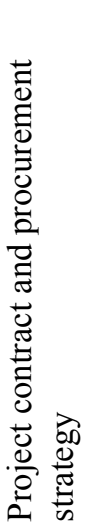 \\
\hline & ن̈ & $\sum_{\text {D }}$ & $\hat{\mathrm{\theta}}$ & $\sum_{U}$ & 它 & $\sum_{0}$ & ப' & $\sum$ & 㝋 & $\stackrel{\mathscr{V}}{\mathscr{G}}$ & v & $\stackrel{m}{0}$ & U & $\hat{a}$ & $\mathscr{\infty}$ \\
\hline
\end{tabular}


For equipment, contractor management and contractor financial stability are the most highly ranked sources of equipment shortage. This is because the contractor who is responsible for many of management arrangements for equipment choice and enabling in site. Choosing the right type and number of equipment is one of the contractor responsibilities. Maintenance program of the construction equipment is one of the management tasks the contractor has to perform to make sure that the piece of equipment is correct to work when it is required. Contractor financial ability is very important to equipment facilities in construction sites. Any defect in contractor financial stability will affect the availability of equipment in site. The complexity level of the project has a considerable effect on equipment shortage. If the project is complex or need new equipment types, the possibility of equipment shortage will be recognized.

For information availability, designer management efficiency is the highest-ranked source of information shortage. Designer is responsible for providing all information when it is required. Inefficiency of designer management will affect the information to be provided when it is needed. Quality of design document is the second-highest ranked source of information shortage. Design drawings and specifications provide most of the required design information. Any mistakes, errors, discrepancy of the design document will affect the information availability. Level of project complexity and required technology and efficiency level of communication between project parties have considerable effect on information shortage. The communication channels and level of ease of data getting will affect the information shortage.

For space availability resource, specific site and project characteristics are the most important causes of workspace shortage. Accessibility level of site and level of site congestion will affect the space shortage. Contractor financial and management capabilities have a considerable effect on space shortage as the contractor is responsible for prepare the site to work before work starts. Any inefficiency of contractor management will affect the availability of workspace.

Table 1 shows the mean values for many of root delay cause effect on resource availability being less than 3, and the Likert scale average and standard deviations were above 1.0. This reflects the respondents' diversification with regard of the root delay causes an effect on resources unavailability. Limited number of root delay causes can ascertain the acceptance conditions shown above as influential on resource unavailability. To enhance the precision, round two of the questionnaire was conducted to a selected group from the first-round participants using the Delphi technique.

\section{Delphi Method Application}

Delphi method is applied to validate and enhance the significance level of the data collected. Many shortcomings could result from the first-round process of interviews such as misunderstanding, carelessness or tiredness due to the issue of the time consumption of filling the questionnaire. Therefore, a second round of a questionnaire interview would enhance the quality of the data collected and strengthen the certified information. The Delphi technique is a popular method developed to verify data collection. It is a systematic technique to induce expert's opinion and obtain the relative importance of multiple criteria (Dalkey, 1970). Delphi technique aims at reaching the most averaging from the experts by many repetitive cycles.

The Delphi method allows questionnaire round-one participants to create a collaborative environment through a series of questionnaires circulation along with related feedback toward additional discussion at following rounds.

In Delphi method, the round-one collected data from the experts are analyzed statistically and then feedbacked to selected participants of round-one.

Shneiderman, 1988 stated that, as an advantage of using Delphi method, all participants are firmly engaged in the process of the evaluation, because it permits suggestions and reevaluation of what criteria and objectives to be part of the analysis toward producing additional agreement on selected criteria and objectives. 
First, round-one of the interview questionnaire results was statistically analyzed. Second, the resulted averages from round-one interview were presented to a selected group of participants as part of round-two of interview questionnaire asking their answers for a second time. Participants were allowed to change their previous responses if they chose so. The presented averages of the second-round participants were grouped into two categories: the total sample average and respondents' round-one responses. To apply Delphi method, eight participants joined in the second-round interview questionnaire, and they were around $26.7 \%$ of the initial-round group. The chosen eight participants were based on availability and acceptance to contribute in the second round of interview questionnaire.

\section{Delphi Method: Root Causes and Effect on Resources'Shortage}

Table 2 presents the mean values and standard deviation for the effect of root delay causes on resources' shortage of round-two analysis. Figure 4 presents the change of mean values and standard deviation between the two rounds of questionnaire for the root delay causes an effect on material shortages. Figure 4 shows the enhancement of the mean values and standard deviations. The same situation is applied for all other types of resources resulting in enhancing mean and standard deviations values. The mean values are increased while the standard deviations were reduced. For example, most of the calculated values are greater than 3 and standard deviation values less than 1 .

To test the degree of agreement regarding the effect between the two rounds of questionnaire, correlation analysis is used. Table 3 shows the correlation factors between the two groups of questionnaire rounds. The calculated correlations coefficient is ranging between ( 0.704 to 0.925$)$. Table 3 shows that there is a very good correlation between the two groups of rounds. This indicating that the enhancement of mean values does not affect the general effect ranking.

This indicating that the enhancement of mean value and reducing standard deviation is statistically valid and prove the Delphi technique to enhance theoretical model bases. 


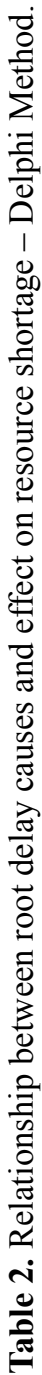

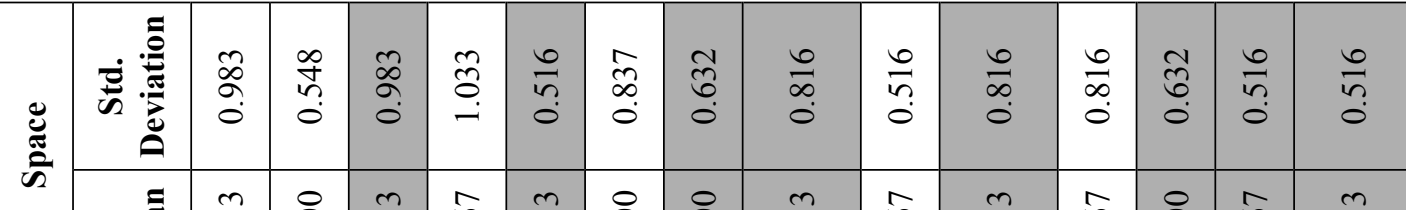

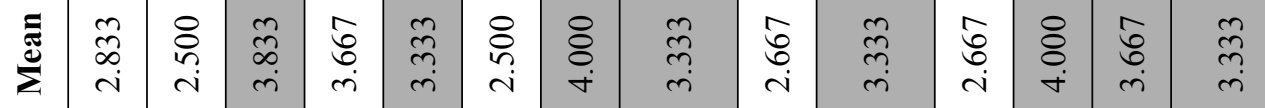

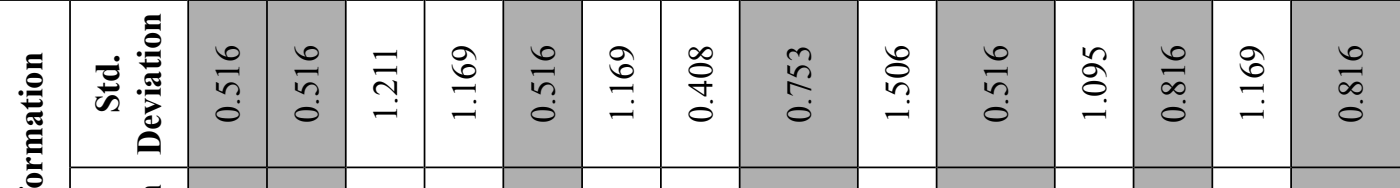

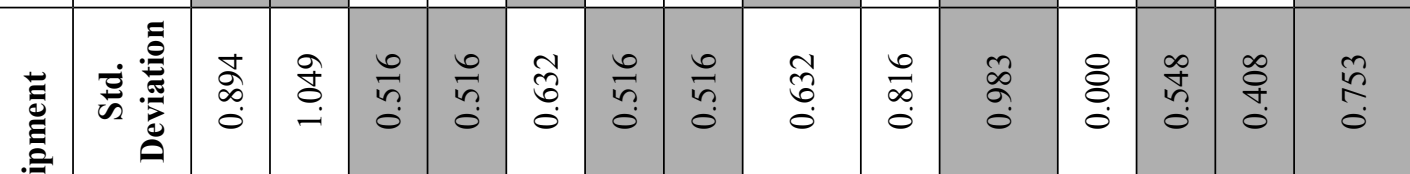

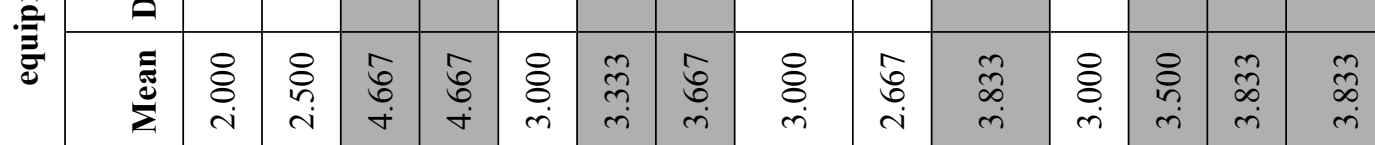

\begin{tabular}{|c|c|c|c|c|c|c|c|c|c|c|c|c|c|c|}
\hline 官 & $\hat{\infty}$ & 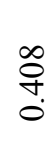 & \& & $\frac{0}{n}$ & ô & $\stackrel{n}{n}$ & $\begin{array}{l}\infty \\
\stackrel{+}{+} \\
0\end{array}$ & \& & $\begin{array}{l}0 \\
\tilde{n} \\
0\end{array}$ & $\begin{array}{l}0 \\
\stackrel{0}{0} \\
0\end{array}$ & $\bar{\nabla}$ & $\begin{array}{l}\infty \\
\text { ñ } \\
0\end{array}$ & $\frac{0}{n}$ & $\frac{0}{n}$ \\
\hline
\end{tabular}

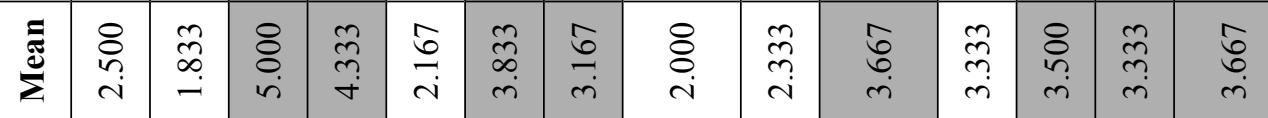

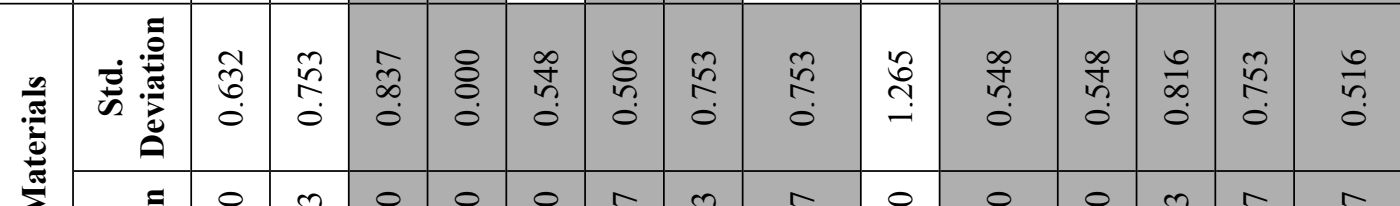

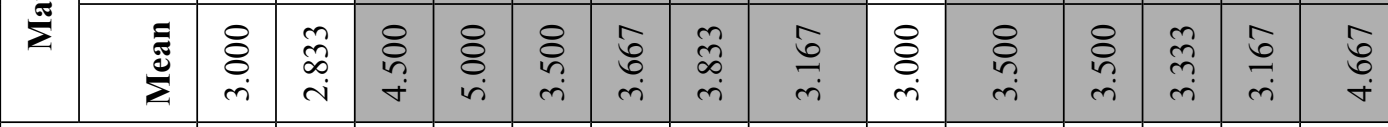

\begin{tabular}{|c|c|c|c|c|c|c|c|c|c|c|c|c|c|c|}
\hline 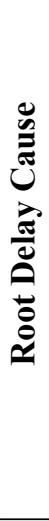 & 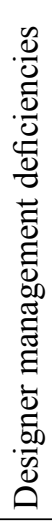 & 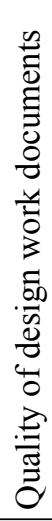 & 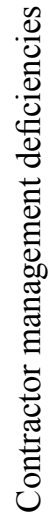 & 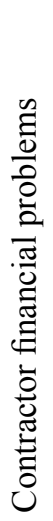 & 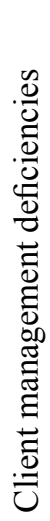 & 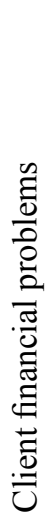 & 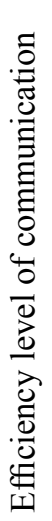 & 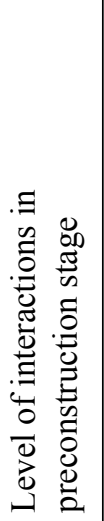 & 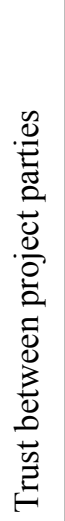 & 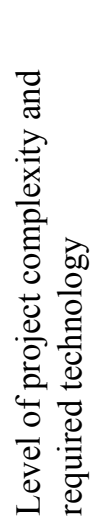 & 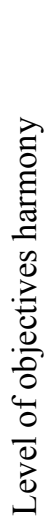 & 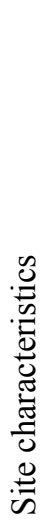 & 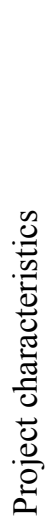 & 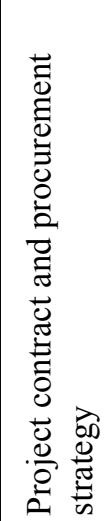 \\
\hline ن & 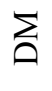 & $\hat{\mathrm{\theta}}$ & $\sum_{U}$ & 志 & $\Sigma$ & O & $\sum$ & 乬 & $\stackrel{\mathscr{f}}{F}$ & 七 & ڤै & U & $\hat{a}$ & $\tilde{\Omega}$ \\
\hline
\end{tabular}




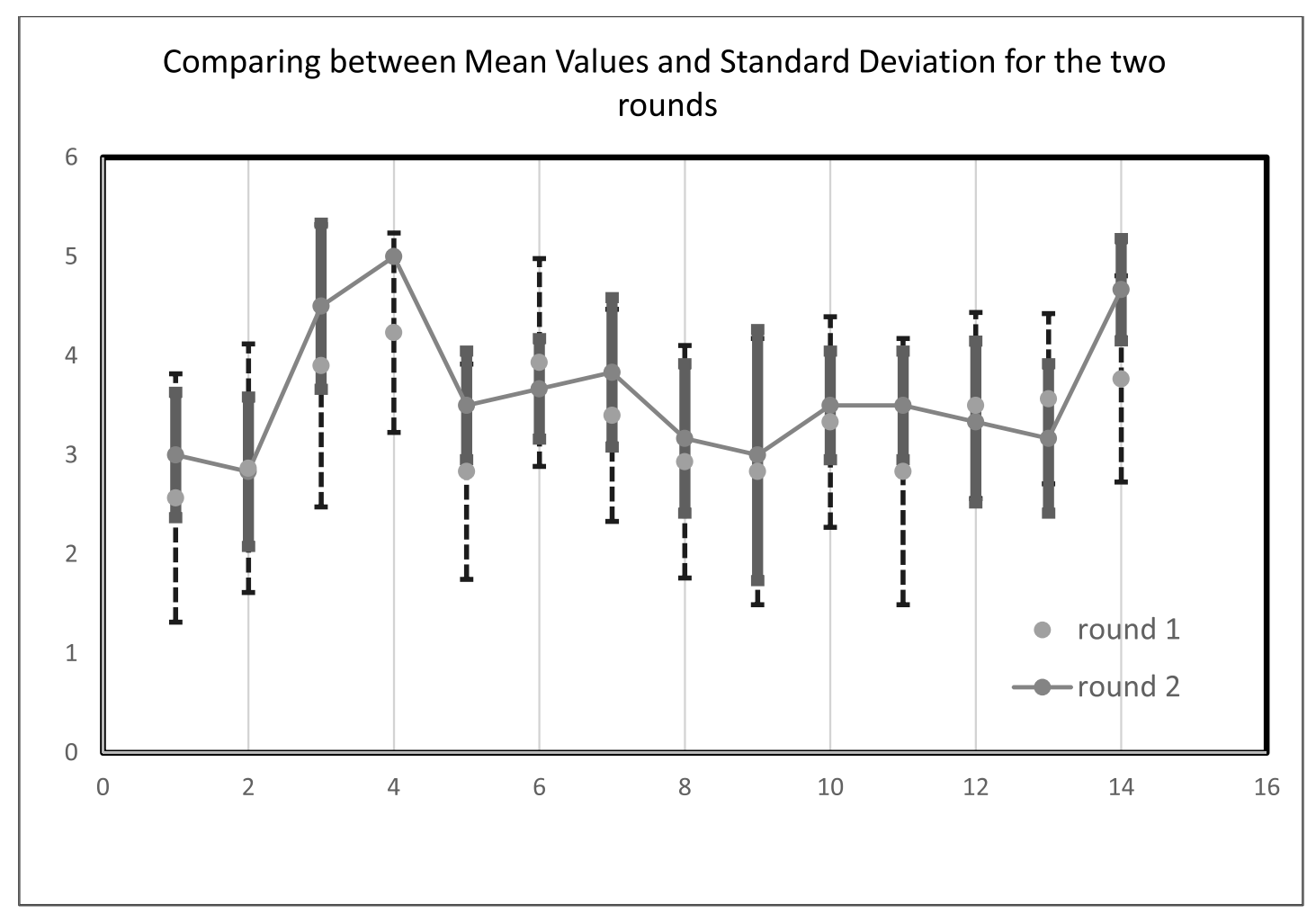

Fig.4. Comparing statistical elements between the two rounds of questionnaires.

Round two results show that the root delay causes that resulted above have different effect on resource availability. For each type of resource, there are special important set of root delay causes. Based on these values we can conclude that:

- Most of the root delay causes ascertained conditions of acceptance for at least three of resources

- Three root delay causes ascertained the predefined conditions of acceptance for all types of resources. These root delay causes are:

- Level of project complexity and required technology

- Site characteristics

- Project contract and procurement strategy

- The root delay cause titled "Trust between project parties" does not ascertain the acceptance conditions, this root delay cause can be excluded from the theoretical basis.

- Two root delay causes named; designer management deficiencies and quality of design work documents have only accepted levels for information resource. 
Table 3. Correlation factors between the two rounds of questionnaires.

\begin{tabular}{|c|c|c|c|}
\hline \multicolumn{4}{|c|}{ Correlations Factors } \\
\hline & & Material -1 & Material -2 \\
\hline \multirow[t]{2}{*}{ Material -1 } & Correlation Coefficient & 1.000 & $.704^{\star \star}$ \\
\hline & Sig. (2-tailed) & & 0.005 \\
\hline \multirow[t]{2}{*}{ Material -2 } & Correlation Coefficient & $.704^{\star \star}$ & 1.000 \\
\hline & Sig. (2-tailed) & 0.005 & \\
\hline & & Labor-1 & Labor-2 \\
\hline \multirow[t]{2}{*}{ Labor-1 } & Correlation Coefficient & 1.000 & $.893^{\star \star}$ \\
\hline & Sig. (2-tailed) & & 0.000 \\
\hline \multirow[t]{2}{*}{ Labor-2 } & Correlation Coefficient & $.893^{\star *}$ & 1.000 \\
\hline & Sig. (2-tailed) & 0.000 & \\
\hline & & Equipment-1 & Equipment-2 \\
\hline \multirow[t]{2}{*}{ Equipment-1 } & Correlation Coefficient & 1.000 & $.853^{\star \star}$ \\
\hline & Sig. (2-tailed) & & 0.000 \\
\hline \multirow[t]{2}{*}{ Equipment-2 } & Correlation Coefficient & $.853^{\star *}$ & 1.000 \\
\hline & Sig. (2-tailed) & 0.000 & \\
\hline & & Information-1 & Information-2 \\
\hline \multirow[t]{2}{*}{ Information-1 } & Correlation Coefficient & 1.000 & $.901^{\star \star}$ \\
\hline & Sig. (2-tailed) & & 0.000 \\
\hline \multirow[t]{2}{*}{ Information-2 } & Correlation Coefficient & $.901^{\star \star}$ & 1.000 \\
\hline & Sig. (2-tailed) & 0.000 & \\
\hline & & Space-1 & Space-2 \\
\hline \multirow[t]{2}{*}{ Space-1 } & Correlation Coefficient & 1.000 & $.925^{\star *}$ \\
\hline & Sig. (2-tailed) & & 0.000 \\
\hline \multirow[t]{2}{*}{ Space-2 } & Correlation Coefficient & $.925^{\star *}$ & 1.000 \\
\hline & Sig. (2-tailed) & 0.000 & \\
\hline \multicolumn{4}{|c|}{${ }^{* *}$. Correlation is significant at the 0.01 level (2-tailed). } \\
\hline & Zorrelation is significar & ne 0.05 level (2 & d). \\
\hline
\end{tabular}

Table 4 shows the root delay causes that ascertain the predefined acceptance conditions for all root delay causes. To get an absolute rank of the root delay causes an effect on resource availability, the ranking order is used to calculate absolute rank. For example, if a root delay cause in the first rank, it takes 10 points and if a root delay cause does not ascertain the acceptance condition, it takes 0 , then calculate values for all resources' types. The resulted top-ranked root delay causes based on their effect on resource availability were as follows:

- Contractor management deficiencies

- Level of project complexity and required technology

- Efficiency level of communication

- Project contract and procurement strategy

- Contractor financial problems

Based on Delphi method, it can be concluded that the foundation of that root delay causes and their effect on resource unavailability is moderately statistically accepted. 


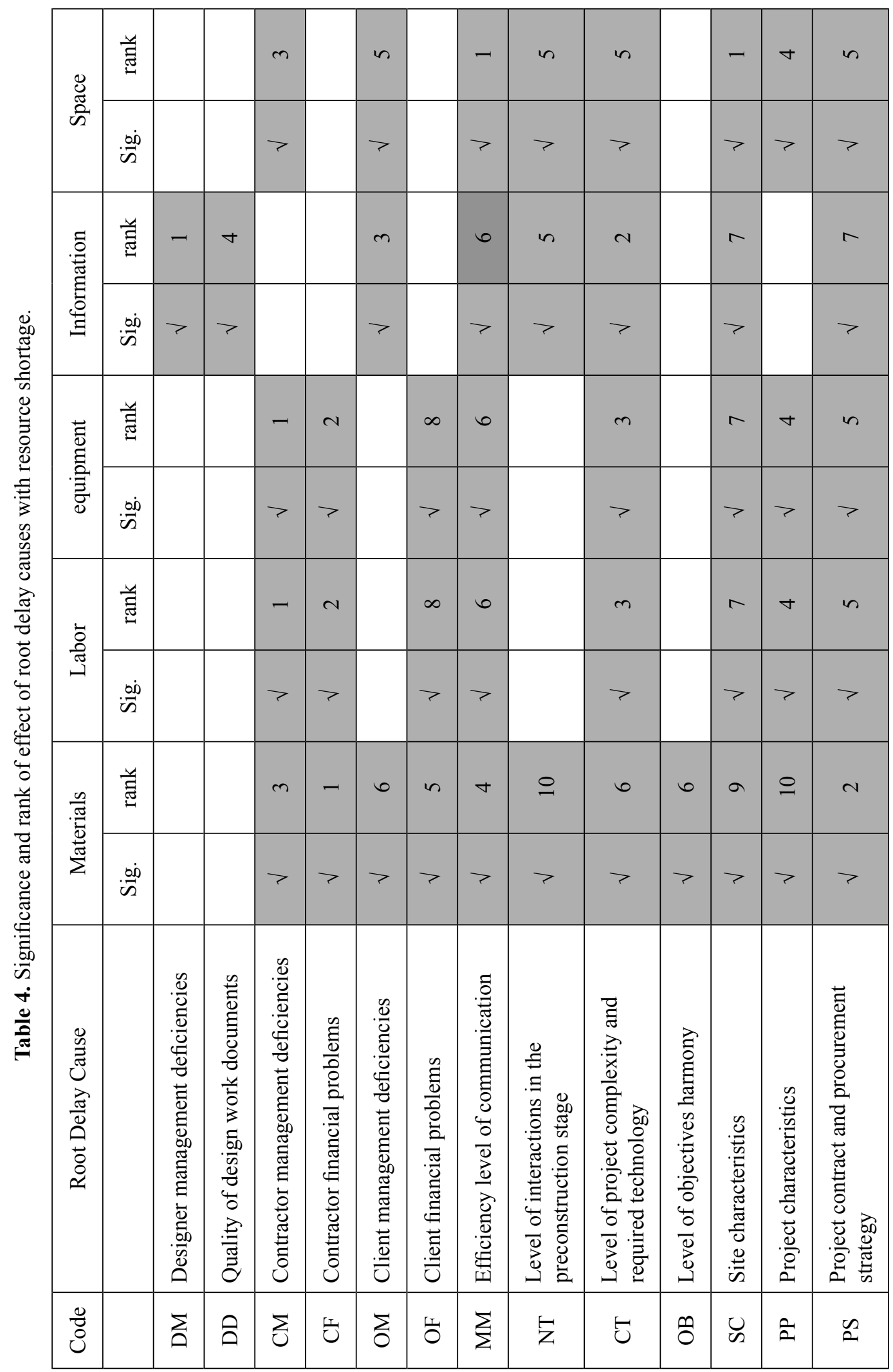




\section{CONCLUSION}

Construction projects delay is a well-known problem, and there were many efforts done to study this problem. Most of these studies concentrated on direct delay causes and little was done to discuss why it happens. This research aimed at bridging the distance between delay causes and delay occurrence in a theoretical form. A proposed theoretical model is suggested to study how the delay occurs in construction projects. The theoretical model is based on three assumptions, that is, linking the delay occurrence with a set of root delay causes, resource availability, and dynamic nature of the construction project. The model proposes that resource unavailability is the underpinning of project delay. The model supposes that delay is generated in a certain period and then propagates during the project life.

The theoretical model is verified through interview with construction experts in two rounds of interview questionnaire. Delphi method was deployed to improve the gathered data in round one interview questionnaire. Based on Delphi method statistical analysis, the analysis ascertains that the root delay causes have different level of effects on resources availability. The most important root delay causes that have significant effect on resource availability were as follows: contractor management deficiencies, level of project complexity and required technology, efficiency level of communication, project contract and procurement strategy, and contractor financial problems. In general, Delphi results verified the principals of the proposed theoretical model.

\section{RECOMMENDED FUTURE WORKS}

A mathematical model will be proposed based on mentioned proposed theoretical model described in this study. The mathematical model can be used to predict the prone for construction project delay.

\section{RESEARCH LIMITATION}

This model is dealing with the managerial and financial reasons that can affect the project delay. These reasons do not contain the external force major reasons.

\section{REFERENCES}

Alkass, S., Mazerolle M. and Harris, F. 1996. Construction delay analysis techniques. Construction Management and Economics, 14: 375-394.

Al-Khalil, M. and Al-Ghafly, M. 1999. Important Causes of Delay in Public Utility Projects in Saudi Arabia. Construction Management and Economics, 17: 647-655

Andersen B and Fagerhaug T. 2006. Root cause analysis. In: Hytinen A and O'Mara P (eds.) "Root cause analysis: Simplified tools and techniques". 2ed. Milwaukee: ASQ Press.

Arditi, D. \& Pattanakitchamroon, T. 2008. Analysis methods in time- based claims. Journal of Construction Engineering Management, 134(4): 242-252.

Assaf, S.A. \& Al-Hejji, S. 2006. Causes of delay in large construction projects. International Journal of Project Management, 24: 349-357.

Aurisicchio M, Bracewell R and Hooey BL. 2016. Rationale mapping and functional modelling enhanced root cause analysis. Safety Science, 85: 241-257.

Bajjou, M.S., \& Chafi, A. 2018. Empirical study of schedule delay in Moroccan construction projects. International Journal of Construction Management. doi:10.1080/15623599.2018.1484859

Baldwin, J., James, M., Harold, R and Harris, R. 1971. Causes of Delay in Construction Industry. Journal of the Construction Division, ASCE: 177-187

Battikha M.G. 2008. Reasoning mechanism for construction non-conformance root-cause analysis. Journal of Construction Engineering and Management, 134(4): 280-288

Benjamin, Jack and Cornell, C. Allan. 1970. Probability, Statistics, and Decision for Civil Engineers. McGraw Hill, NY. 
Bubshait, A. and Cunningham, M. 1998. Comparison of Delay Analysis Methodologies. Journal of Construction Engineering and Management, vol. 124(4): 315-322.

Callahan, M.T., Quackenbush, D.G. and Rowings, J.E. 1992. Construction Project Scheduling” John Wiley \& Sons, NY.

Chen, I.J. and Paulraj, A. 2004. Towards a theory of supply chain management: the constructs and measurements. Journal of Operations Management, 22: 119-150.

Clough, R. and Sears, G. 1994. Construction Contracts". John Wiley Sons, New York, sixth edition.

Clough, R., Sears, G. and Sears, S. K. 2000. Construction Project Management. John Willey and Sons, New York; Chichester.

Dalkey, N. 1970. Use of Self-rating to improve Group Estimates. American Elsevier Pub. Co. Inc.

Gor, D. and Pitroda, J. 2018. The Impact of Supply Chain Management Practice on Construction Project Performance in the Central Gujara. International Journal of Technical Innovation in Modern Engineering \& Science (IJTIMES), Volume 4(5): $269-275$

Ho, W. Tian Zheng, Hakan Yildiz \& Srinivas Talluri (2015). Supply chain risk management: a literature review, International Journal of Production Research, 53:16: 5031-5069, DOI: 10.1080/00207543.2015.1030467

Hsu, Pei-Yuan, Aurisicchio, M. and Angeloudis, P. 2017. Investigating Schedule Deviation in Construction Projects through Root Cause Analysis. CENTRES- International Conference on Enterprise Information System/ ProjMAN- International Conference on Project MANagement / HCist - International Conference on Health and Social Care Information system and Technologies, CENTERIS/ ProMAN/ HCist, 8-10, Barcelona, Spain

Iyer, K.C. and Jha, K.N. 2006. Critical factors affecting schedule performance: evidence from Indian construction projects. Journal of Construction Engineering and Management, Vol. 132(8): 871-881.

Kor, Y.Y and Mahoney, J.T. 2004. Edith Penrose's (1595) Contributions to the resource-based view of strategic management, Journal of Management Studies, 41(1): 183-191.

Krosnick, J.A. and Alwin, D.F. 1987. An evaluation of a cognitive theory of response order effects in survey management. Public Opinion Quarterly, 51: 201-219.

Mahdi, I., \& Soliman, E. 2018. Significant and top-ranked delay factors in Arabic Gulf countries. International Journal of Construction Management. doi:10.1080/15623599.2018.1512029

Meng, X. 2012. The effect of relationship management on project performance in construction. International Journal of Project Management, 30: 188-198

Mohamad, M.R.B. 2010. The factors and effect of delay in government Construction project, Case study in kuantan: University Malaysia Pahang.

Muneeswaran, G., Manoharan, P., Awoyera, P.O., \& Adesina, A. 2018. A statistical approach to assess the schedule delays and risks in Indian construction industry. International Journal of Construction Management. doi:10.1080/15623599.2018.1484991

Nagaraju, S., Reddy, B.S. and Chaudhuri, A.R. 2012. Resource Management in Construction Projects - a case study. Engineering Science and Technology: An International Journal (ESTIJ), 2(4): 660-665

Rachid, Z., Toufik, B., \& Mohammed, B. 2018. Causes of schedule delays in construction projects in Algeria. International Journal of Construction Management, 1-11. doi:10.1080/15623599.2018.1435234

Ramanathan, C., Narayanan, S. and Idrus, A. 2012. Construction Delays Causing Risks on Time and Cost - a Critical Review. Australasian Journal of Construction Economics and Building, 12(1): 37-57.

Ramlee, N.1, Tammy, N.J., Raja Mohd Noor, R.N.H., Ainun Musir, A., Abdul Karim, N., Chan, H.B., Mohd Nasir. 2015. Critical Success Factors For Construction Project. S.R. International Conference on Advanced Science, Engineering and Technology (ICASET), 1-6

Rosenfeld, Y. 2013. Root-cause analysis of construction-cost overruns. Journal of Construction Engineering and Management, 140(1): 04013039-1-10.

Ruqaishi, M. and Bashir, H.A. 2013. Causes of delay in construction projects in the oil and gas industry in the Gulf cooperation council countries: a case study", Journal of Management in Engineering, 31(3): 5014017. 
Saiful Islam, M. and Trigunarsyah, B. 2017. Construction Delays in Developing Countries: A Review”. KICEM Journal of Construction Engineering and Project Management, 7(1): 1-17.

Shebob, A., Dawood, N., Shah, R.K. and Xu, Q. 2012. Comparative study of delay factors in Libyan and the UK construction industry. Engineering, Construction and Architectural Management, 19(6): 688-712.

Shneiderman, M.V. 1988. Empirical Studies of Procedures for Forming Group Judgement, Plenum Publishing Corporation.

Soliman, E. 2006. Delay Hierarchy Propagation Model. A Thesis Submitted to The University of Plymouth in Partial Fulfilment for The Degree of Doctor of Philosophy.

Soliman, E. 2017. Root Delay Causes for Construction Projects. International Journal of Innovative Research in Science, Engineering and Technology, 6(4).

Soomro, M.A., Shah, S.A. and Abro, S.A. 2016. A Chronological Review of Factor Research on Time Delays in Construction Industry. World Journal of Engineering Research and Technology Wjert, 2(4): 170 -195.

SPSS, statistical analysis software, version 24.

Stumpf, G.R. 2000. Schedule delay analysis. Cost Engineering-Ann Arbor Then Morgantown, 42(7): 32-32.

Sweis, R. Moarefi, A., Amiri, M.H., Moarefi, S. and Saleh, R. 2018. Causes of delay in Iranian oil and gas projects: a root cause analysis. International Journal of Energy Sector Management, https://doi.org/10.1108/IJESM-04-2018-0014

Wibowo, M. and Sholeh, M. 2015. The Analysis of Supply Chain Performance Measurement at Construction Project. Procedia Engineering, 125: 25-31

Yang, J and Kao, C. 2009. Review of delay analysis methods: A Process-Based Comparison. The Open Construction and Building Technology Journal, 3: 81-89

Zayed, T. and Kalavagunta, R. 2005. Delays in Construction Industry. $6^{\text {th }}$ Construction speciality Conference, Toronto, June 2-4, 2005.

\section{Appendix 1}

\section{Part one:}

\section{Introduction}

The project delays problem is one of the main problems in the construction industry. Many examples for causes of delays can be recorded and noticed during the project construction phase such as owner financial problems, mistakes in drawings, delay in shop drawing approvals, delay of material delivery, and planning and scheduling inefficiency.

It is noted that these delays are physical or real delays that occurred. It is proposed that these real delays are outcomes of some earlier events that later become real delays. These events are called root delay causes. These root delay causes are either managerial or financial problems from any of project parties.

In this research, a theoretical model is proposed to describe why project delay occurs? The model is suggested that there are some of root delay causes that are the basics for delay occurrence. These root delay causes will affect the efficiency of resources supply chain efficiency. Any deficiency of resource management will produce real delay occurrence, then resulting project delay. The real delay is a direct influence of resources supply chain efficiency. Fourteen delay causes resulted from previous research work will be used in this research to evaluate their relationship with resource management efficiency.

This questionnaire aims to verify the idea of root delay causes and their effect on resource supply chain efficiency.

We are seeking your help participating in this questionnaire; the results of this research will be fed back to you. If you can participate in this questionnaire, your help and effort will be appreciated. Your answer will be treated as strictly confidential.

\section{Research authors}




\section{Participant General Information}

Please define

1- You are working for

in construction industry
○ Client
- Contractor
○ Consultant-designer

2- Your position can be described as one of the following levels of management:
- Site management
- Middle management
○ Top management

3- How many years of experience in the construction industry
- Less than 15 years
- From 15 to 20
○ More than 20 years

4- You have experience in

(you can tick more than one)
○ Design Work
○ Site Management
- Cost Estimation
- Contract Analysis
- Site Supervision
○ Quantity Survey
- Claim Analysis

\section{Part 2: Evaluation of the relationship between root delay causes and main resources shortage}

Main resources required to implement any construction activity are:

- Construction Material: The required material either individual, mixed or fabricated material resource required permitting activity to start and finish.

- Labor: Required technical, skilled and unskilled labor associated to execute project activities.

- Equipment: Any required piece of equipment associated to execute project activities.

- Information: Any required design, supervision, coordination, orientation information required to execute activity

- Work Space: The required space and environment facilities required to permit activity to start and finish.

In this part, the list of root delay causes is presented, and you are asked to evaluate each one of the listed rood delay cause on resource management efficiency. The level of impact is ranged from very highly impact to very low impact in 5 Likert scale. 


\section{1- Material Shortage:}

\begin{tabular}{|c|c|c|c|c|c|c|}
\hline \multirow{2}{*}{\multicolumn{2}{|c|}{ Root delay cause }} & \multicolumn{5}{|c|}{ Material shortage } \\
\hline & & \multirow[t]{2}{*}{$\mathrm{VH}$} & \multirow[t]{2}{*}{$\mathrm{H}$} & \multirow[t]{2}{*}{ A } & \multirow[t]{2}{*}{$\mathrm{L}$} & \multirow[t]{2}{*}{ VL } \\
\hline 1 & Designer management efficiency & & & & & \\
\hline 2 & Quality of design work documents & & & & & \\
\hline 3 & Contractor financial stability & & & & & \\
\hline 4 & Contractor management capabilities & & & & & \\
\hline 5 & Client management efficiency & & & & & \\
\hline 6 & Client financial stability & & & & & \\
\hline 7 & $\begin{array}{l}\text { Efficiency Level of Communication between } \\
\text { Project Parts }\end{array}$ & & & & & \\
\hline 8 & $\begin{array}{l}\text { Level of interactions between project parties in } \\
\text { the preconstruction phase }\end{array}$ & & & & & \\
\hline 9 & Level of Trust between project parties & & & & & \\
\hline 10 & $\begin{array}{l}\text { Level of Project Complexity and Required } \\
\text { Technology }\end{array}$ & & & & & \\
\hline 11 & $\begin{array}{l}\text { Level of objectives harmony between project } \\
\text { parties }\end{array}$ & & & & & \\
\hline 12 & $\begin{array}{l}\text { Specific characteristics (location, underground, } \\
\text { weather, environmental, etc.) }\end{array}$ & & & & & \\
\hline 13 & Specific site and project characteristics & & & & & \\
\hline 14 & Project contract and procurement strategy & & & & & \\
\hline
\end{tabular}

$\mathrm{VH}=$ Very High Effect

$\mathrm{H}=$ High Effect

$A=$ Average Effect

$\mathrm{L}=$ Low Effect

$\mathrm{VL}=$ Very Low Effect 


\section{2: Labor Shortage:}

\begin{tabular}{|c|c|c|c|c|c|c|}
\hline \multirow{2}{*}{\multicolumn{2}{|c|}{ Root delay cause }} & \multicolumn{5}{|c|}{ Labor shortage } \\
\hline & & \multirow[t]{2}{*}{$\mathrm{VH}$} & \multirow[t]{2}{*}{$\mathrm{H}$} & \multirow[t]{2}{*}{ A } & \multirow[t]{2}{*}{$\mathrm{L}$} & \multirow[t]{2}{*}{ VL } \\
\hline 1 & Designer management efficiency & & & & & \\
\hline 2 & Quality of design work documents & & & & & \\
\hline 3 & Contractor financial stability & & & & & \\
\hline 4 & Contractor management capabilities & & & & & \\
\hline 5 & Client management efficiency & & & & & \\
\hline 6 & Client financial stability & & & & & \\
\hline 7 & $\begin{array}{l}\text { Efficiency Level of Communication between } \\
\text { Project Parts }\end{array}$ & & & & & \\
\hline 8 & $\begin{array}{l}\text { Level of interactions between project parties in } \\
\text { the preconstruction phase }\end{array}$ & & & & & \\
\hline 9 & Level of Trust between project parties & & & & & \\
\hline 10 & $\begin{array}{l}\text { Level of Project Complexity and Required } \\
\text { Technology }\end{array}$ & & & & & \\
\hline 11 & $\begin{array}{l}\text { Level of objectives harmony between project } \\
\text { parties }\end{array}$ & & & & & \\
\hline 12 & $\begin{array}{l}\text { Specific characteristics (location, underground, } \\
\text { weather, environmental, etc.) }\end{array}$ & & & & & \\
\hline 13 & Specific site and project characteristics & & & & & \\
\hline 14 & Project contract and procurement strategy & & & & & \\
\hline
\end{tabular}

$\mathrm{VH}=$ Very High Effect

$\mathrm{H}=$ High Effect

$\mathrm{A}=$ Average Effect

$\mathrm{L}=$ Low Effect

$\mathrm{VL}=$ Very Low Effect 


\section{3- Equipment Shortage:}

\begin{tabular}{|c|c|c|c|c|c|c|}
\hline \multirow{2}{*}{\multicolumn{2}{|c|}{ Root delay cause }} & \multicolumn{5}{|c|}{ Equipment shortage } \\
\hline & & \multirow[t]{2}{*}{$\mathrm{VH}$} & \multirow[t]{2}{*}{$\mathrm{H}$} & \multirow[t]{2}{*}{ A } & \multirow[t]{2}{*}{$\mathrm{L}$} & \multirow[t]{2}{*}{ VL } \\
\hline 1 & Designer management efficiency & & & & & \\
\hline 2 & Quality of design work documents & & & & & \\
\hline 3 & Contractor financial stability & & & & & \\
\hline 4 & Contractor management capabilities & & & & & \\
\hline 5 & Client management efficiency & & & & & \\
\hline 6 & Client financial stability & & & & & \\
\hline 7 & $\begin{array}{l}\text { Efficiency Level of Communication between } \\
\text { Project Parts }\end{array}$ & & & & & \\
\hline 8 & $\begin{array}{l}\text { Level of interactions between project parties in } \\
\text { the preconstruction phase }\end{array}$ & & & & & \\
\hline 9 & Level of Trust between project parties & & & & & \\
\hline 10 & $\begin{array}{l}\text { Level of Project Complexity and Required } \\
\text { Technology }\end{array}$ & & & & & \\
\hline 11 & $\begin{array}{l}\text { Level of objectives harmony between project } \\
\text { parties }\end{array}$ & & & & & \\
\hline 12 & $\begin{array}{l}\text { Specific characteristics (location, underground, } \\
\text { weather, environmental, etc.) }\end{array}$ & & & & & \\
\hline 13 & Specific site and project characteristics & & & & & \\
\hline 14 & Project contract and procurement strategy & & & & & \\
\hline
\end{tabular}

$\mathrm{VH}=$ Very High Effect

$\mathrm{H}=$ High Effect

$A=$ Average Effect

$\mathrm{L}=$ Low Effect

$\mathrm{VL}=$ Very Low Effect 


\section{4- Information Shortage:}

\begin{tabular}{|c|c|c|c|c|c|c|}
\hline & & & & ion & & \\
\hline Ro & t delay cause & VH & $\mathrm{H}$ & A & $\mathrm{L}$ & VL \\
\hline 1 & Designer management efficiency & & & & & \\
\hline 2 & Quality of design work documents & & & & & \\
\hline 3 & Contractor financial stability & & & & & \\
\hline 4 & Contractor management capabilities & & & & & \\
\hline 5 & Client management efficiency & & & & & \\
\hline 6 & Client financial stability & & & & & \\
\hline 7 & $\begin{array}{l}\text { Efficiency Level of Communication between } \\
\text { Project Parts }\end{array}$ & & & & & \\
\hline 8 & $\begin{array}{l}\text { Level of interactions between project parties in } \\
\text { the preconstruction phase }\end{array}$ & & & & & \\
\hline 9 & Level of Trust between project parties & & & & & \\
\hline 10 & $\begin{array}{l}\text { Level of Project Complexity and Required } \\
\text { Technology }\end{array}$ & & & & & \\
\hline 11 & $\begin{array}{l}\text { Level of objectives harmony between project } \\
\text { parties }\end{array}$ & & & & & \\
\hline 12 & $\begin{array}{l}\text { Specific characteristics (location, underground, } \\
\text { weather, environmental, etc.) }\end{array}$ & & & & & \\
\hline 13 & Specific site and project characteristics & & & & & \\
\hline 14 & Project contract and procurement strategy & & & & & \\
\hline
\end{tabular}

$\mathrm{VH}=$ Very High Effect

$\mathrm{H}=$ High Effect

$\mathrm{A}=$ Average Effect

$\mathrm{L}=$ Low Effect

$\mathrm{VL}=$ Very Low Effect 


\section{5- Space Shortage:}

\begin{tabular}{|c|c|c|c|c|c|c|}
\hline \multirow{2}{*}{\multicolumn{2}{|c|}{ Root delay cause }} & \multicolumn{5}{|c|}{ Space shortage } \\
\hline & & \multirow[t]{2}{*}{$\mathrm{VH}$} & \multirow[t]{2}{*}{$\mathrm{H}$} & \multirow[t]{2}{*}{ A } & \multirow[t]{2}{*}{$\mathrm{L}$} & \multirow[t]{2}{*}{ VL } \\
\hline 1 & Designer management efficiency & & & & & \\
\hline 2 & Quality of design work documents & & & & & \\
\hline 3 & Contractor financial stability & & & & & \\
\hline 4 & Contractor management capabilities & & & & & \\
\hline 5 & Client management efficiency & & & & & \\
\hline 6 & Client financial stability & & & & & \\
\hline 7 & $\begin{array}{l}\text { Efficiency Level of Communication between } \\
\text { Project Parts }\end{array}$ & & & & & \\
\hline 8 & $\begin{array}{l}\text { Level of interactions between project parties in } \\
\text { the preconstruction phase }\end{array}$ & & & & & \\
\hline 9 & Level of Trust between project parties & & & & & \\
\hline 10 & $\begin{array}{l}\text { Level of Project Complexity and Required } \\
\text { Technology }\end{array}$ & & & & & \\
\hline 11 & $\begin{array}{l}\text { Level of objectives harmony between project } \\
\text { parties }\end{array}$ & & & & & \\
\hline 12 & $\begin{array}{l}\text { Specific characteristics (location, underground, } \\
\text { weather, environmental, etc.) }\end{array}$ & & & & & \\
\hline 13 & Specific site and project characteristics & & & & & \\
\hline 14 & Project contract and procurement strategy & & & & & \\
\hline
\end{tabular}

$\mathrm{VH}=$ Very High Effect

$\mathrm{H}=$ High Effect

$A=$ Average Effect

$\mathrm{L}=$ Low Effect

$\mathrm{VL}=$ Very Low Effect 